\title{
Serum fatty acid-binding protein 4 levels and responses of pancreatic islet $\beta$-cells and $\alpha$-cells in patients with type 2 diabetes
}

Hong Wang ${ }^{1+}$, Jie Cao ${ }^{1 \dagger}$, Jian-bin Su ${ }^{1 *} \mathbb{B}$, Xue-qin Wang ${ }^{1 *}$, Xing Wang ${ }^{1}$, Dong-mei Zhang ${ }^{2}$ and Xiao-hua Wang ${ }^{1}$

\begin{abstract}
Background: Serum fatty acid-binding protein 4 (FABP4), as an intracellular lipid chaperone and adipokine, was reported to be related to the incidence of type 2 diabetes (T2D) and diabetic complications, but its association with pancreatic islet $\beta$-cell and a-cell functions has not been fully elucidated. So the present study was to investigate the serum FABP4 levels and responses of islet $\beta$-cells and a-cells in patients with T2D.
\end{abstract}

Methods: 115 patients with T2D and 89 healthy controls $(\mathrm{HC})$, who received serum FABP4 levels test, were recruited to participate in this study. Moreover, 75-g oral glucose tolerance test (OGTT) was performed in T2D patients to evaluate islet $\beta$-cell and a-cell functions. Systemic insulin sensitivity and overall insulin secretion of islet $\beta$-cell function were assessed by Matsuda index using $C$ peptide (ISI $\left.\right|_{M-c p}$ ) and ratio of the area under the $C$ peptide curve to the glucose curve $\left(A \cup C_{c p / g \mid u}\right.$ ) during OGTT, respectively. Fasting glucagon (Gluca $a_{0 \text { in }}$ ) and postchallenge glucagon assessed by the area under the glucagon curve $\left(A \cup C_{\text {gluca }}\right)$ were determined during OGTT to evaluate islet a-cell function. And other various clinical variables were also measured in all participants. Skewed variables were natural log-transformed (In), such as InFABP4.

Results: The serum FABP4 levels in T2D patients were significantly higher than those in $\mathrm{HC}(p<0.05)$. And after partially adjusting for fasting plasma glucose, serum InFABP4 levels were negatively correlated with $\left.|n| S\right|_{M-c p}(r=-0.332$, $p<0.001)$ and positively correlated with $\operatorname{InAUC}_{\mathrm{cp} / \mathrm{glu}}(r=0.324, p<0.001)$, InGluca $\mathrm{omin}_{\mathrm{in}}(r=0.200, p=0.040)$ and $\operatorname{InAUC}$ gluca $(r=0.311, p<0.001)$, respectively, in patients with T2D. Furthermore, when multiple linear regression analyses were applied to adjust for other various clinical variables, serum InFABP4 levels were found to remain associated with InISI $\left.\right|_{M-c p}(\beta=-0.296, t=-2.900, p=0.005)$, InAUC $C_{c p / g l u}(\beta=0.223, t=2.038, p=0.046)$, InGluca $_{0 \text { min }}(\beta=0.272$, $t=2.330, p=0.024)$ and $\ln A \cup C_{\text {gluca }}(\beta=0.341, t=3.065, p=0.004)$, respectively.

Conclusion: Increased serum FABP4 levels were closely associated with blunted insulin sensitivity, increased insulin secretion, and elevated fasting and postchallenge glucagon levels in patients with T2D.

Keywords: FABP4, $\beta$-cell function, a-cell function, Type 2 diabetes

*Correspondence: sujbzjx@163.com; wangxueqin108@163.com ${ }^{\dagger}$ Hong Wang and Jie Cao contributed equally to this work ${ }^{1}$ Department of Endocrinology, Affiliated Hospital 2 of Nantong University, and First People's Hospital of Nantong City, No. 6, Haierxiang North Road, Nantong 226001, China

Full list of author information is available at the end of the article

\section{Background}

Type 2 diabetes (T2D) has been known as 'bi-hormonal disorder', with pancreatic islet $\beta$-cell dysfunction responsible for the incidence and progression of T2D [1] and aberrant $\alpha$-cell secretion responsible for the exacerbation of glycemic disorders $[2,3]$. The core pathogenesis of T2D involves islet $\beta$-cell and $\alpha$-cell dysfunctions. Pancreatic islet $\beta$-cell dysfunction of T2D is presented with blunted 
insulin sensitivity and/or abnormal insulin secretion, and islet $\alpha$-cell dysfunction is characterized by elevated fasting glucagon and impaired repression of glucagon secretion after oral glucose load [4-7]. At present, ongoing research efforts worldwide are trying to screen risk factors for pancreatic islet $\beta$-cell and $\alpha$-cell dysfunctions, which can help guide development of appropriate therapeutic regimens to improve these dysfunctions.

Fatty acid-binding protein 4 (FABP4), as a member of the FABPs family, is mainly expressed in adipocytes and macrophages. Circulating FABP4 mainly secreted from adipocytes and macrophages seems to not only function as lipid chaperone for the fatty acids transportation, storage and metabolism in target organs, but also serves as a bioactive adipokine in several target cells, including adipocytes, macrophages, endothelial cells, etc [8].

Under pathological conditions, excessive or ectopic expression of FABP4 was demonstrated to play an important role in the incidence and progression of metabolic diseases, such as metabolic syndrome and T2D. Increased levels of serum FABP4 have been found to be associated with increased risk of T2D in several follow-up studies $[9,10]$. Moreover, in recent studies, increased serum FABP4 levels were also shown to predict the occurrence of micro- and macro-vascular complications in T2D, such as diabetic retinopathy (DR), diabetic nephropathy $(\mathrm{DN})$, coronary artery disease $(\mathrm{CAD})$ and acute ischemic stroke (AIS) [11-14]. Therefore, we hypothesized that increased serum FABP4 levels may get involved with the core pathogenesis of T2D. Some previous studies had shown that serum FABP4 levels were negatively correlated with the glucose-disposal rate in T2D $(n=18)$ [15] and positively correlated with glucose-stimulated insulin secretion in non-diabetic humans $(n=17)$ [16]. However, so far, there are few studies that have comprehensively analyzed the associations of serum FABP4 levels with overall pancreatic islet $\beta$-cell and $\alpha$-cell functions in patients with T2D.

Therefore, the present study was conducted to systemically investigate the serum FABP4 levels and responses of $\beta$-cells and $\alpha$-cells in patients with T2D.

\section{Methods}

\section{Study design}

We posted an announcement at the Department of Endocrinology and Health Examination Center of Affiliated Hospital 2 of Nantong University to recruit patients with T2D and healthy controls (HC), respectively, for this study from April 2019 to September 2020. The inclusion criteria for patients with T2D were as follows: (1) aged from 20 to 75 years, (2) diagnosis of T2D based on the statement published by the American Diabetes Association in 2015 [17]. The exclusion criteria for patients with T2D were as follows: (1) type 1 diabetes and other types of diabetes, (2) hyperglycemic crisis, (3) severe cardiac, hepatic or renal disease, (4) previous malignant tumors, (5) thyroid dysfunction, (6) recent use of glucocorticoids or immunosuppressive agents, (7) systemic autoimmune diseases. The inclusion criteria for $\mathrm{HC}$ participants were as follows: (1) aged from 20 to 75 years, (2) fasting plasma glucose (FPG) in the range of 3.9 and $6.1 \mathrm{mmol} / \mathrm{L}$, (3) negative medical histories, (4) normal physical examinations, (5) normal hematological indices, (6) normal lipid profiles, (7) normal liver and renal function tests, (8) normal resting electrocardiograms.

Finally, $115 \mathrm{~T} 2 \mathrm{D}$ patients and $89 \mathrm{HC}$ were recruited for the present study. The study was approved by the Ethics Committee of Affiliated Hospital 2 of Nantong University and followed the principles of the Declaration of Helsinki. Furthermore, each participant provided an informed consent when they were enrolled.

\section{Clinical variables collection}

Demographic information was collected, such as age, gender, height, weight, waist circumference (WC) and blood pressure. Waist circumference (WC) was measured at the level of umbilicus. Body mass index (BMI) was determined as weight divided to height squared $(\mathrm{kg} /$ $\mathrm{m}^{2}$ ). Systolic blood pressure (SBP) and diastolic blood pressure (DBP) were measured by an automatic blood pressure monitor after at least $30 \mathrm{~min}$ of rest. In patients with $\mathrm{T} 2 \mathrm{D}$, glucose-lowering therapies were also collected, such as lifestyle alone, insulin treatments, insulin secretagogues, metformin, pioglitazone, $\alpha$-glucosidase inhibitors (AGIs), glucagon-like peptide-1 receptor agonists (GLP-1RAs) and dipeptidyl peptidase-4 inhibitors (DPP-4Is).

Peripheral fasting blood samples were collected after fasting for at least $8 \mathrm{~h}$ for the measurement of FPG, highdensity lipoprotein cholesterol (HDLC), low-density lipoprotein cholesterol (LDLC), triglycerides (TG), total cholesterol (TC), serum creatinine (SCr) and uric acid (UA). Moreover, patients with T2D were received glycosylated hemoglobin (HbA1c) test. Renal function was assessed by estimated glomerular filtration rate (eGFR), which was calculated using the equation from Modification of Diet in Renal Disease (MDRD) Study [18]. Additionally, fasting blood samples were also drawn and centrifuged at $3000 \mathrm{~g}$ for $10 \mathrm{~min}$, immediately divided into aliquots, and frozen at $-80{ }^{\circ} \mathrm{C}$ until centralized analysis for FABP4 levels. Serum FABP4 levels were measured by Solid Phase Sandwich ELISA at Medical Research Center (Human FABP4 Quantikine ELISA Kit; R\&D Systems). 


\section{Assessment of pancreatic islet $\beta$-cell and $\alpha$-cell functions}

All patients with T2D also underwent a 75-g oral glucose tolerance test (OGTT) for assessment of pancreatic islet $\alpha$-cell and $\beta$-cell functions. Venous blood samples were collected at fasting $(0 \mathrm{~min})$ and at 30, 60, 120 , and 180 min after glucose loading for the synchronous determination of serum glucose, $\mathrm{C}$-peptide and glucagon levels. We used C-peptide instead of insulin in the $\beta$-cell function indices to eliminate cross-contamination of exogenous insulin with detection reagents. Systemic insulin sensitivity and overall insulin secretion of islet $\beta$-cell function were assessed by Matsuda index using $C$ peptide ( ISI $_{\mathrm{M} \text {-cp }}$ ) [19] and ratio of the area under the $\mathrm{C}$ peptide curve to the glucose curve $\left(\mathrm{AUC}_{\mathrm{cp} / \mathrm{glu}}\right)$ during OGTT, respectively. Fasting glucagon $\left(\right.$ Gluca $\left._{0 \text { min }}\right)$ and postchallenge glucagon assessed by the area under the glucagon curve $\left(\mathrm{AUC}_{\text {gluca }}\right)$ were determined during OGTT to evaluate islet $\alpha$-cell function.

\section{Statistical analysis}

Clinical variables are displayed for patients with T2D and healthy controls (HC), and are expressed as mean \pm standard deviation for normally distributed data, as the median( $25 \%$ and $75 \%$ interquartile range) for skewed continuous data and as the frequency(percentage) for categorical data. To compare the differences in clinical variables between the two groups, Student's t-tests, Mann-Whitney $U$ tests or chi-square tests were used as appropriate, and corresponding test statistics $\left(t, Z\right.$ and $\chi^{2}$ values) and $p$ values were also provided. If the data was non-normally distributed, a natural logarithm transformation (ln) was applied to achieve a normal distribution for further correlation and regression analysis, such as $\operatorname{lnFABP} 4, \operatorname{lnISI}_{\mathrm{M}-\mathrm{cp}}, \ln \mathrm{nUC}_{\mathrm{cp} / \mathrm{glu}}$ lnGluca $_{0 \min }$ and $\ln \mathrm{AUC}$ gluca*

Pearson's bivariate correlation analyses were applied to explore the correlations of $\operatorname{lnFABP} 4$ with $\operatorname{lnISI}_{\mathrm{M}-\mathrm{cp}}$, $\ln \mathrm{AUC}_{\mathrm{cp} / \text { glu }}, \ln \mathrm{Gluca}_{0 \mathrm{~min}}, \ln \mathrm{AUC} \mathrm{Cluca}_{\text {gla }}$ and other metabolic variables. Considering that FPG may have an effect on the FABP4 levels, the correlations of InFABP4 with $\operatorname{lnISI} I_{\mathrm{M} \text {-cp }}, \ln \mathrm{AUC}_{\mathrm{cp} / \mathrm{glu}}, \operatorname{lnGluca_{0\operatorname {min}}}$ and $\ln \mathrm{AUC}_{\text {gluca }}$ were adjusted for FPG by partial correlation analyses.

Furthermore, multiple linear regression analyses were applied to adjust for other various clinical variables in order to explore the independent effects of lnFABP4 on $\operatorname{lnISI}_{\mathrm{M}-\mathrm{cp}}, \ln A \mathrm{UC}_{\mathrm{cp} / \mathrm{glu}}, \ln \operatorname{lluca}_{0 \mathrm{~min}}$ and $\ln \mathrm{AUC}_{\text {gluca. }}$. The initial model 0 was unadjusted; model 1 was adjusted for age, gender, BMI, WC, diabetic duration, SBP, DBP, TG, TC, HDLC, LDLC, eGFR, UA, FPG, HbA1c and glucoselowering therapies. SPSS for Windows, standard version 23.0 (IBM Co., Armonk, NY, USA) was used to input and analyse the clinical variables, and $p$ value $<0.05$ could be considered statistically significant.

\section{Results}

Characteristics of $\mathrm{HC}$ and patients with T2D

Characterisitics of clinical variables in $\mathrm{HC}$ and patients with T2D were shown in Table 1. Serum FABP4 levels of $\mathrm{HC}$ and patients with T2D were $9498.46(5168.19-14406.19) \quad \mathrm{pg} / \mathrm{ml}$ and 17535.96 (9513.62-28436.53) $\mathrm{pg} / \mathrm{ml}$, respectively. And serum FABP4 levels were obviously higher in patients with T2D than in HC $(p<0.001)$, which was also graphically displayed in Fig. 1. Moreover, serum FABP4 levels were found to be higher in female with T2D than in male with T2D $(p=0.012)$, with respective levels of $22677.00(14964.61-34450.90) \mathrm{pg} / \mathrm{ml}$ and 16003.61 (8255.95-25362.95) pg/ml. Additionally, T2D patients had a higher male ratio, SBP, BMI and FPG, and a lower HDLC levels when compared to $\mathrm{HC}$ (all $p<0.05$ ). However, there were no differences in age, DBP, TG, TC, LDLC, eGFR and serum UA between the HC and patients with T2D.

\section{Correlations of FABP4 with clinical variables}

Pearson's bivariate correlation analyses were applied to explore the correlations of $\operatorname{lnFABP} 4$ with metabolic variables (Table 2) and indices of islet $\beta$-cell function ( $\operatorname{lnISI}_{\mathrm{M} \text {-cp }}$ and $\left.\ln A U C_{\mathrm{cp} / \mathrm{glu}}\right)$ and $\alpha$-cell function ( $\operatorname{lnGluca}_{0 \min }$ and $\ln \mathrm{AUC}_{\text {gluca }}$ ) (Table 3). Serum $\ln \mathrm{FABP} 4$ was positively correlated with LDLC $(r=0.247, p=0.020)$ in $\mathrm{HC}$, and was positively correlated with FPG and UA in patients with T2D $(r=0.299$ and 0.248 , respectively, $p<0.05)$. Moreover, serum $\operatorname{lnFABP} 4$ levels were found to be related to $\operatorname{lnISI} I_{\mathrm{M}-\mathrm{cp}}, \ln \mathrm{AUC}_{\mathrm{cp} / \mathrm{glu}}$ and $\ln \mathrm{AUC}_{\text {gluca }}(r=-0.266$, 0.247 and 0.304 , respectively, $p<0.05$ ), but correlation of $\operatorname{lnFABP} 4$ with $\ln$ Gluca $_{0 \mathrm{~min}}$ did not attain statistical significance $(r=0.175, p=0.074)$. Furthermore, after adjusting for FPG by partial correlation analyses, correlations of $\operatorname{lnFABP4}$ with $\operatorname{lnISI} \mathrm{M}_{\mathrm{M} \text {-cp }}, \ln \mathrm{AUC}_{\mathrm{cp} / \mathrm{glu}}, \operatorname{lnGluca}_{0 \min }$ and $\ln \mathrm{AUC}_{\text {gluca }}$ became more evident $(r=-0.332,0.324$, 0.200 and 0.311 , respectively, $p<0.05$ ). Scatter pots for these correlations were also displayed in Fig. 2 and Fig. 3.

Additionally, serum $\operatorname{lnFABP} 4$ levels were found to be correlated with C-peptide and glucagon levels at each point after glucose loading (Table 3). Serum lnFABP4 levels were correlated with $\operatorname{lnISI} I_{\mathrm{M}-\mathrm{cp}}(r=-0.414, p=0.018)$ in T2D patients without any glucose-lowering therapy $(n=32)$, and were correlated with $\operatorname{lnISI} \mathrm{M}_{\mathrm{M} \text { cp }}$ and $\ln \mathrm{AUC}$ cp/glu $(r=-0.223$ and 0.331 , respectively, $p<0.05)$ in T2D patients with glucose-lowering therapies $(n=83)$ (Additional file 2: Figure S1). And the correlations of $\operatorname{lnFABP} 4$ with $\operatorname{lnISI} I_{\mathrm{M}-\mathrm{cp}}$ and $\ln \mathrm{AUC}_{\mathrm{cp} / \mathrm{glu}}$ remained significant in patients with T2D after adjusting for the glucose-lowering therapies $(r=-0.265$ and 0.235 , 
Table 1 Characterisitics of clinical variables in $\mathrm{HC}$ and patients with T2D

\begin{tabular}{|c|c|c|c|c|}
\hline Variables & $\mathrm{HC}$ & T2D & $t / Z / x^{2}$ value & $p$ value \\
\hline$n$ & 89 & 115 & - & - \\
\hline Female, n (\%) & $47(52.8)$ & $42(36.5)$ & 5.412 & 0.020 \\
\hline Age (years) & $55.06 \pm 8.82$ & $55.32 \pm 11.42$ & 0.128 & 0.856 \\
\hline BMI $\left(\mathrm{kg} / \mathrm{m}^{2}\right)$ & $23.00 \pm 2.42$ & $24.92 \pm 3.81$ & 4.375 & 0.001 \\
\hline WC $(\mathrm{cm})$ & - & $90.80 \pm 9.41$ & - & - \\
\hline SBP $(m m H g)$ & $121.53 \pm 10.98$ & $132.84 \pm 16.39$ & 5.890 & $<0.001$ \\
\hline $\mathrm{DBP}(\mathrm{mmHg})$ & $78.17 \pm 7.53$ & $79.21 \pm 10.70$ & 0.823 & 0.412 \\
\hline Diabetic duration (year) & - & $8(2-10)$ & - & - \\
\hline \multicolumn{5}{|l|}{ Glucose-lowering therapies } \\
\hline Lifestyle alone, n (\%) & - & $32(27.8)$ & - & - \\
\hline Insulin treatments, n(\%) & - & $35(30.4)$ & - & - \\
\hline Insulin secretagogues, n (\%) & - & 39 (33.9) & - & - \\
\hline Metformin, n (\%) & - & $53(46.1)$ & - & - \\
\hline Pioglitazone, n (\%) & - & $10(8.7)$ & - & - \\
\hline AGIs, n (\%) & - & $13(11.3)$ & - & - \\
\hline GLP-1RAs, n (\%) & - & $1(0.9)$ & - & - \\
\hline DPP-4Is, n (\%) & - & $8(7.0)$ & - & - \\
\hline FPG (mmol/L) & $5.18 \pm 0.48$ & $11.07 \pm 3.58$ & 17.426 & $<0.001$ \\
\hline TG (mmol/L) & $1.33(1.01-1.86)$ & $1.47(0.96-2.84)$ & 1.415 & 0.157 \\
\hline $\mathrm{TC}(\mathrm{mmol} / \mathrm{L})$ & $4.72 \pm 0.72$ & $4.73 \pm 1.48$ & 0.053 & 0.958 \\
\hline HDLC (mmol/L) & $1.45 \pm 0.32$ & $1.17 \pm 0.31$ & -6.107 & $<0.001$ \\
\hline LDLC (mmol/L) & $3.00 \pm 0.62$ & $2.91 \pm 1.04$ & -0.737 & 0.462 \\
\hline $\operatorname{eGFR}\left(\mathrm{ml} / \mathrm{min} / 1.73 \mathrm{~m}^{2}\right)$ & $128.36(92.48-151.86)$ & $121.81(90.93-146.78)$ & -3.427 & 0.078 \\
\hline Serum UA (umol/L) & $295.90 \pm 75.06$ & $317.00 \pm 115.21$ & 1.532 & 0.127 \\
\hline $\mathrm{HbA1c}(\%)$ & - & $9.60 \pm 2.07$ & - & - \\
\hline FABP4 (pg/ml) & $\begin{array}{l}9498.46 \\
(5168.19-14406.19)\end{array}$ & $\begin{array}{l}17535.96 \\
(9513.62-28436.53)\end{array}$ & 6.107 & $<0.001$ \\
\hline
\end{tabular}

Student t-tests, Mann-Whitney $\mathrm{U}$ tests and Chi-square tests were applied to detect differences in their corresponding type of data, and corresponding test statistics $(t$, $Z$ and $x^{2}$ values) and $p$ values were also provided

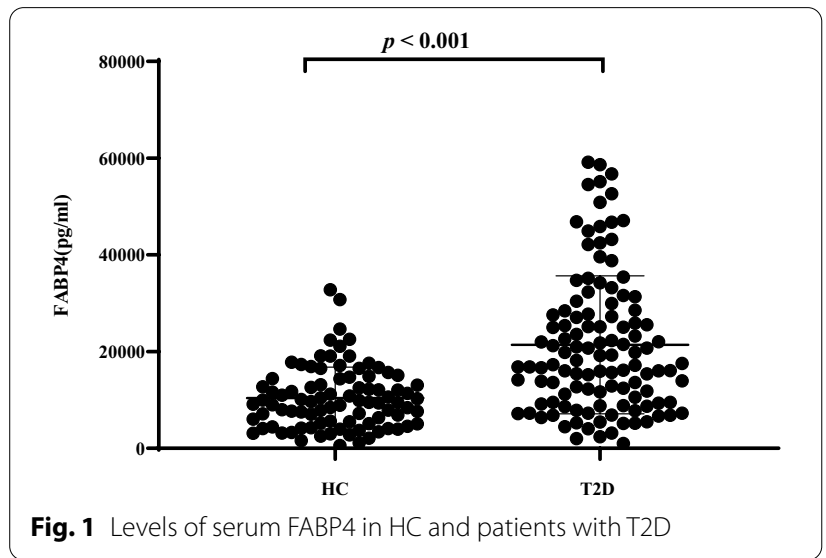

respectively, $p<0.05$ ) (Additional file 3: Figure S2). Serum $\operatorname{lnFABP} 4$ levels were also correlated with area under the C peptide curve from 0 to 30 min during OGTT (AUC cp0-30 min $)$ in patients with T2D $(r=0.276, p=0.003)$
Table 2 Correlations between the serum InFABP4 and major metabolic variables in $\mathrm{HC}$ and patients with $\mathrm{T} 2 \mathrm{D}$

\begin{tabular}{|c|c|c|c|c|}
\hline \multirow[t]{2}{*}{ Variables } & \multicolumn{2}{|l|}{$\mathrm{HC}$} & \multicolumn{2}{|l|}{ T2D } \\
\hline & $r$ & $p$ value & $r$ & $p$ value \\
\hline FPG (mmol/L) & -0.056 & 0.604 & 0.299 & 0.002 \\
\hline TG (mmol/L) & 0.096 & 0.373 & 0.066 & 0.494 \\
\hline TC (mmol/L) & 0.010 & 0.923 & -0.097 & 0.312 \\
\hline $\mathrm{HDLC}(\mathrm{mmol} / \mathrm{L})$ & 0.023 & 0.834 & -0.050 & 0.608 \\
\hline LDLC (mmol/L) & 0.247 & 0.020 & -0.152 & 0.120 \\
\hline UA (umol/L) & 0.022 & 0.840 & 0.248 & 0.011 \\
\hline $\operatorname{eGFR}\left(\mathrm{ml} / \mathrm{min} / 1.73 \mathrm{~m}^{2}\right)$ & -0.067 & 0.232 & -0.127 & 0.196 \\
\hline
\end{tabular}

(Additional file 4: Figure S3). When T2D patients were divided into subgroups according to diabetic duration, serum $\operatorname{lnFABP4}$ levels were correlated with $\operatorname{lnISI_{M-cp}}$ $(r=-0.349, p=0.019)$ in T2D patients with diabetic duration $\leq 5$ years, and were correlated with $\operatorname{lnISI} \mathrm{M}_{\mathrm{M}-\mathrm{cp}}$, 
Table 3 Correlations between the serum InFABP4 and indices of $\beta$-cell and a-cell functions in patients with T2D

\begin{tabular}{|c|c|c|}
\hline \multirow[t]{2}{*}{ Variables } & \multicolumn{2}{|l|}{ T2D } \\
\hline & $r$ & $p$ value \\
\hline $\operatorname{lnCP_{0\operatorname {min}}}(\mathrm{ng} / \mathrm{ml})$ & 0.235 & 0.011 \\
\hline $\operatorname{lnCP} P_{30 \min }(\mathrm{ng} / \mathrm{ml})$ & 0.264 & 0.005 \\
\hline $\operatorname{lnCP}{ }_{60 \min }(\mathrm{ng} / \mathrm{ml})$ & 0.257 & 0.006 \\
\hline $\operatorname{lnCP}{ }_{120 \min }(\mathrm{ng} / \mathrm{ml})$ & 0.226 & 0.016 \\
\hline $\operatorname{lnCP}{ }_{180 \min }(\mathrm{ng} / \mathrm{ml})$ & 0.317 & 0.001 \\
\hline InGluca ${ }_{0 \text { min }}(p g / m l)$ & 0.175 & 0.074 \\
\hline InGluca $30 \min (p g / m l)$ & 0.279 & 0.004 \\
\hline InGluca ${ }_{60 \min }(\mathrm{pg} / \mathrm{ml})$ & 0.312 & 0.001 \\
\hline $\operatorname{InGluca}_{120 \min }(\mathrm{pg} / \mathrm{ml})$ & 0.296 & 0.002 \\
\hline InGluca ${ }_{180 \min }(\mathrm{pg} / \mathrm{ml})$ & 0.295 & 0.002 \\
\hline $\ln |S|_{M-c p}$ & -0.266 & 0.005 \\
\hline $\ln A \cup C_{\mathrm{cp} / \mathrm{glu}}$ & 0.247 & 0.009 \\
\hline $\ln A \cup C_{c p}$ & 0.235 & 0.011 \\
\hline $\ln A \cup C_{\text {gluca }}$ & 0.304 & 0.002 \\
\hline
\end{tabular}

$\ln \mathrm{AUC}_{\mathrm{cp} / \mathrm{glu}}$ and $\ln \mathrm{AUC}_{\mathrm{gluca}}(r=-0.245,0.326$ and 0.328 , respectively, $p<0.05)$ in T2D patients with diabetic duration $>5$ years (Additional file 1: Table S1).

\section{Multiple linear regression analyses exploring the impact} of serum InFABP4 levels on indices of islet $\beta$-cell and $\alpha$-cell functions

Table 4 showed the associations of serum $\operatorname{lnFABP} 4$ levels with islet $\beta$-cell function ( $\mathrm{ISI}_{\mathrm{M} \text {-cp }}, \mathrm{AUC}_{\mathrm{cp} / \mathrm{glu}}$ ) and $\alpha$-cell function (Gluca $_{0 \min }$ and $\mathrm{AUC}_{\text {gluca }}$ ) via multiple linear regression analyses in patients with $\mathrm{T} 2 \mathrm{D}$. In the initial unadjusted model 0 , serum $\operatorname{lnFABP} 4$ levels were significantly related to $\operatorname{lnISI} I_{M-c p}(\beta=-0.266, t=-2.886$, $p=0.005), \quad \ln \mathrm{AUC}_{\mathrm{cp} / \mathrm{glu}}(\beta=0.247, t=2.662, p=0.009)$ and $\ln \mathrm{AUC}_{\text {gluca }}(\beta=0.304, t=3.240, p=0.002)$, but association of lnFABP4 with $\operatorname{lnGluca}_{0 \min }$ did not attain statistical significance $(\beta=0.175, t=1.807, p=0.074)$. After adjusting for the other clinical variables in model 1 , including age, gender, BMI, WC, diabetic duration, SBP, DBP, lipid profiles, eGFR, UA, FPG, HbA1c and glucose-lowering therapies, serum $\ln F A B P 4$ levels remained independently associated with $\operatorname{lnISI}_{\mathrm{M}-\mathrm{cp}}(\beta=-0.296$, $t=-2.900, p=0.005), \ln \mathrm{AUC}_{\mathrm{cp} / \mathrm{glu}}(\beta=0.223, t=2.038$, $\mathbf{a}$

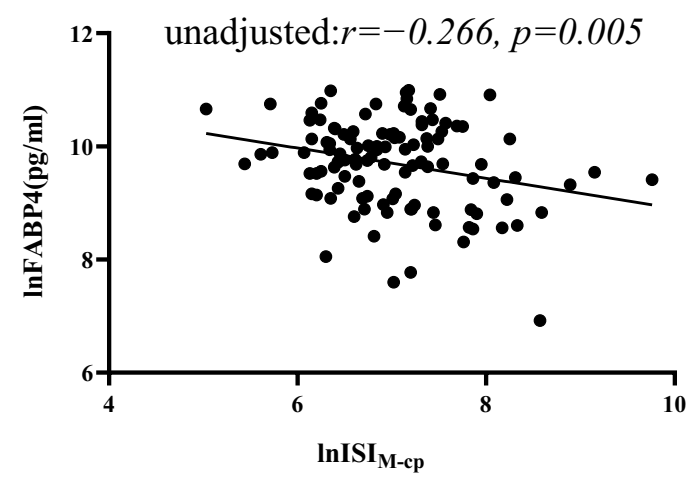

c

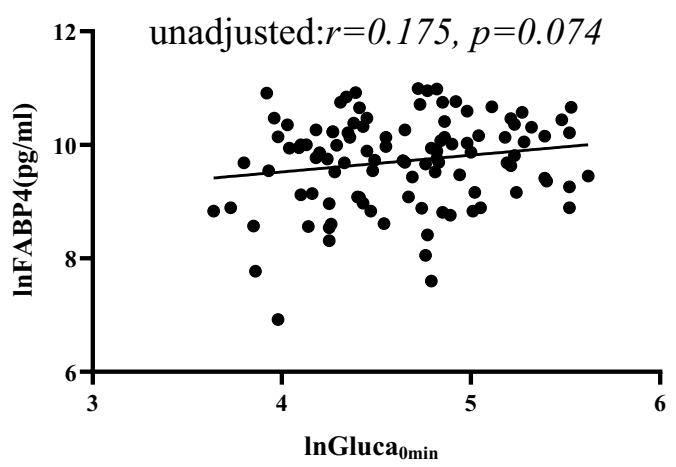

b

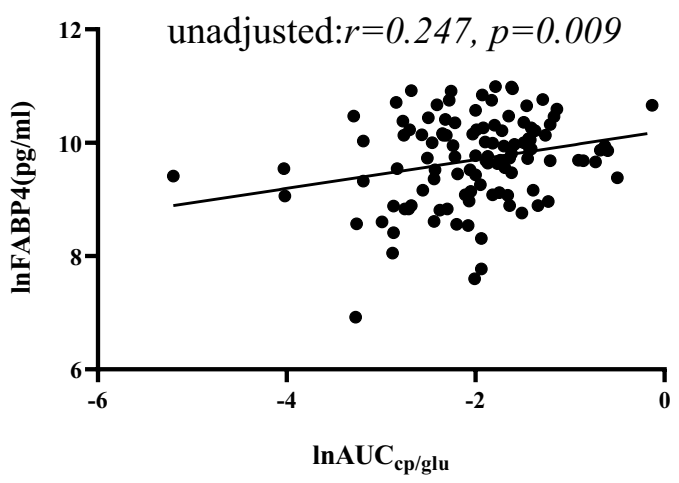

d

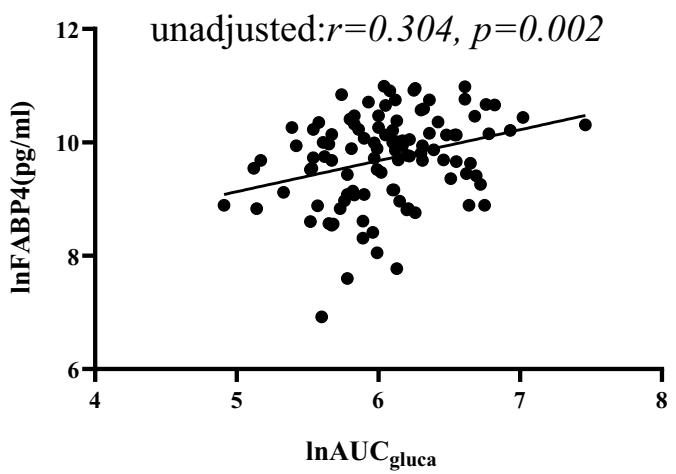

Fig. 2 Relationships between serum FABP4 and islet $\beta$-cell and a-cell function indices in patients with T2D by univariate analysis (a $|S|_{M-c p} ; \mathbf{b} A U C_{c p /}$ glu; c Gluca ${ }_{0 \text { min }}$; $A_{U} \cup C_{\text {gluca }}$ ) 
Table 4 Multivariate linear regression analyses displaying the impact of serum InFABP4 levels on outcomes of InISI $\left.\right|_{M-c p}$ InAUC cp/glu' InGluca ${ }_{0 \text { min }}$ and InAUC $C_{\text {gluca }}$ in patients with T2D

\begin{tabular}{|c|c|c|c|c|}
\hline Models & $\beta$ & $t$ & $p$ & $\begin{array}{l}\text { Adjusted } R^{2} \\
\text { for model }\end{array}$ \\
\hline \multicolumn{5}{|l|}{$\ln |S|_{M-c p}$} \\
\hline Model 0 & -0.266 & -2.886 & 0.005 & 0.062 \\
\hline Model 1 & -0.296 & -2.900 & 0.005 & 0.391 \\
\hline \multicolumn{5}{|l|}{$\ln A \cup C_{\mathrm{cp} / \mathrm{glu}}$} \\
\hline Model 0 & 0.247 & 2.662 & 0.009 & 0.052 \\
\hline Model 1 & 0.223 & 2.308 & 0.046 & 0.351 \\
\hline \multicolumn{5}{|l|}{ InGluca ${ }_{0 \min }$} \\
\hline Model 0 & 0.175 & 1.807 & 0.074 & 0.021 \\
\hline Model 1 & 0.272 & 2.330 & 0.024 & 0.363 \\
\hline \multicolumn{5}{|l|}{ InAUC $C_{\text {gluca }}$} \\
\hline Model 0 & 0.304 & 3.240 & 0.002 & 0.084 \\
\hline Model 1 & 0.341 & 3.065 & 0.004 & 0.407 \\
\hline
\end{tabular}

Model 0: unadjuseted

Model 1: adjusted for age, gender, BMI, WC, diabetic duration, SBP, DBP, lipid profiles, eGFR, UA, FPG, HbA1c and glucose-lowering therapies $p=0.046)$ and $\ln \mathrm{AUC}_{\text {gluca }}(\beta=0.341, t=3.065, p=0.004)$, and became independently associated with $\operatorname{lnGluca}_{0 \mathrm{~min}}$ $(\beta=0.272, t=2.330, p=0.024)$.

\section{Discussion}

In the present study, we compared the difference of serum FABP4 levels between the 115 patients with T2D and 89 healthy controls, and then analyzed the correlations of serum FABP4 levels with indices of pancreatic islet $\beta$-cell and $\alpha$-cell functions. The main findings of our study were as follows: first, patients with T2D were presented with a higher levels of serum FABP4 when compared to healthy subjects; second, serum FABP4 levels were positively correlated with LDLC in healthy subjects and positively correlated with UA and FPG in patients with T2D; third, correlations of serum FABP4 levels with $\mathrm{ISI}_{\mathrm{M} \text {-cp }}, \mathrm{AUC}_{\mathrm{cp} / \mathrm{glu}}$, Gluca ${ }_{0 \text { min }}$ and $\mathrm{AUC}_{\text {gluca }}$ became more evident when partially adjusted for FPG; fourth, after adjusting for other various clinical variables, serum FABP4 levels were found to remain associated with $\mathrm{ISI}_{\mathrm{M}-\mathrm{cp}}, \mathrm{AUC}_{\mathrm{cp} / \mathrm{glu}}, \mathrm{Gluca}_{0 \min }$ and $\mathrm{AUC}_{\text {gluca }}$. Collectively, serum FABP4 levels were in close relation to the indices of pancreatic islet $\beta$-cell and $\alpha$-cell functions.

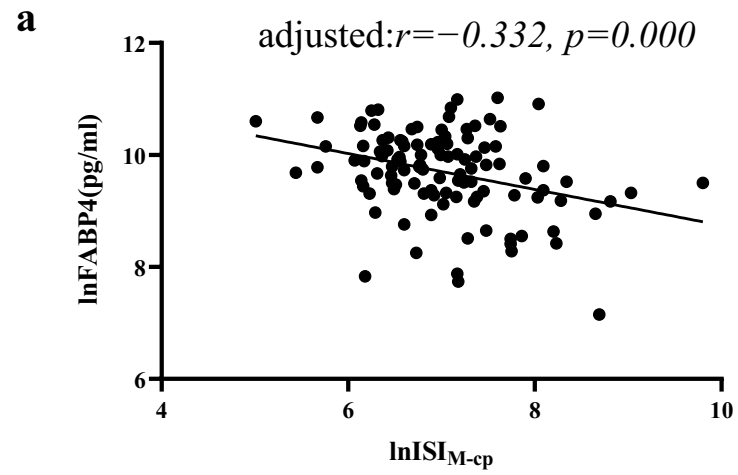

c

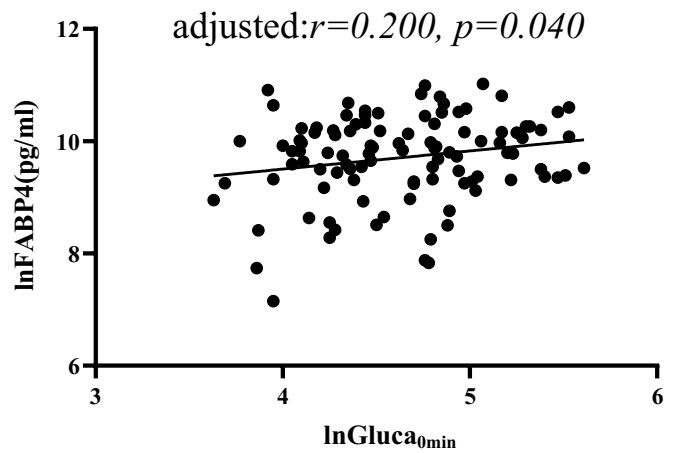

b

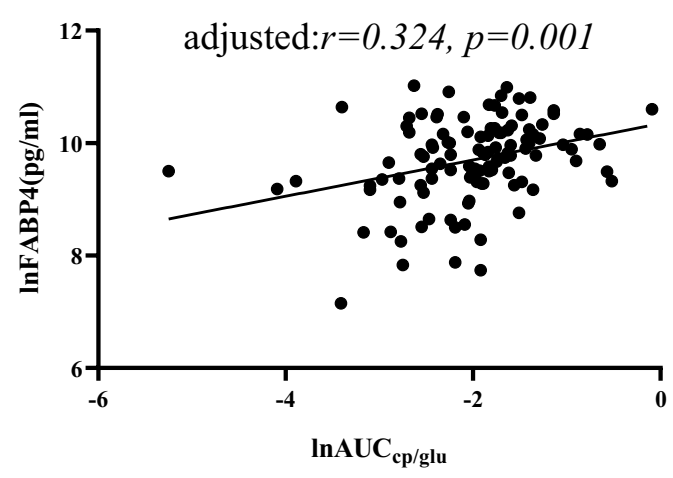

d

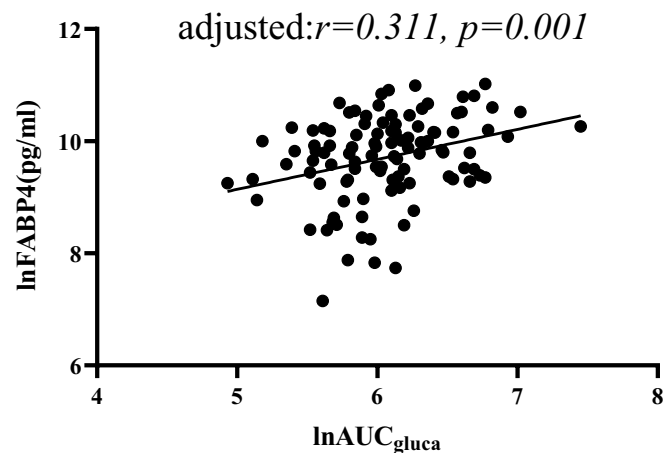

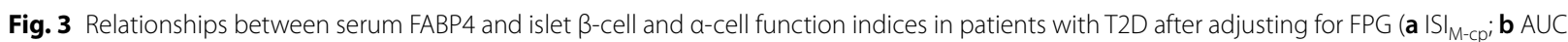
(p/glu; $\mathbf{c} \mathrm{Gluca}_{0 \text { min }} ; \mathbf{d} \mathrm{AUC}_{\text {gluca }}$ ) 


\section{Serum FABP4 levels and metabolic diseases}

Excessive expression or ectopic expression of FABP4 was proven to contribute to the multiple components of metabolic diseases and subsequent adverse outcomes, such as insulin resistance, dyslipidemia, obesity, metabolic syndrome, hypertension, type 2 diabetes, atherosclerosis and cardiovascular diseases [20-23]. In several previous studies, serum FABP4 levels were shown to be obviously increased in obesity and patients with T2D [22-25]. Kim et al [26] found that FABP4 was overexpressed in visceral tissues by proteomic analysis in patients with early T2D. And correlations of increased serum FABP4 levels with subcutaneous and visceral adipose depots evaluated by multi-slice computed tomography were almost the same [27]. Detection of serum FABP4 levels could be reflective of potential risk for metabolic diseases, such as obesity and T2D. FABP4 could enhance liver glucose production in vivo and in vitro, inhibit glucose oxidation and glycolysis, suppress uptake and utilization of glucose in muscles and liver [28], ultimately, lead to an increase in circulating glucose levels. Our study showed serum FABP4 levels were higher in the patients with T2D than in the healthy controls, and were significantly positively correlated with FPG in these T2D patients. Our finding is consistent with the previous studies. Moreover, in our present study, serum FABP4 levels were found to be higher in female with T2D than in male with T2D. And a previous study by Ibarretxe et al [29] also showed that serum FABP4 levels were determined by gender, which is in agreement with our study. The gender-difference of serum FABP4 is possibly due to two-fold: on the one hand, females tend to have a higher amount of body fat than males since there is a close correlation between serum FABP4 levels and adiposity [30]; and on the other hand, androgen may partially account for the gender difference in serum FABP4 levels [31].

\section{Serum FABP4 levels and indices of pancreatic islet $\beta$-cell function}

Since serum FABP4 levels are correlated well with features of metabolic syndrome and are served as a predictor for the development of T2D. It is highly likely that increased serum FABP4 levels are involved in the core pathogenesis of T2D. A pervious study by Niu et al [32] found that serum FABP4 levels were positively correlated with homeostasis model assessment of insulin resistance (HOMA-IR), an indicator of hepatic insulin resistance, in a community population. Nakamura et al [15] found that serum FABP4 levels were negatively correlated with glucose-disposal rate in a small sample of T2D patients. Due to glucose-disposal rate primarily reflecting the sensitivity of skeletal muscle to insulin
[33], increased FABP4 levels were closely related to decreased insulin sensitivity of muscle. Moreover, Nakamura et al [15] also observed that serum FABP4 was positively correlated with insulin secretion at 120 min of meal tolerance test in their study. Additionally, in a study with a cohort of 17 non-diabetic humans with BMI 19 from $36 \mathrm{~kg} / \mathrm{m}^{2}$, Wu et al [16] found serum FABP4 levels were positively correlated with response in glucose-stimulated insulin secretion independence of body fat. And our present study revealed that increased serum FABP4 levels were independently associated blunted insulin sensitivity assessed by $\mathrm{ISI}_{\mathrm{M} \text {-cp }}$ and overall increased insulin secretion of $\beta$-cells assessed by $\mathrm{AUC}_{\mathrm{cp} / \mathrm{glu}}$ in patients with $\mathrm{T} 2 \mathrm{D}$. $\mathrm{ISI}_{\mathrm{M}-\mathrm{cp}}$ is index of systemic insulin sensitivity, and can effectively reflect the sensitivity of the liver and peripheral tissues (mainly muscle) to insulin [19]. After analysis in subgroups, the association of FABP4 with $\mathrm{ISI}_{\mathrm{M}-\mathrm{cp}}$ was persisted in subgroups with and without glucose-lowering therapies, or in subgroups with different diabetic duration; while the significant association of FABP4 with $\mathrm{AUC}_{\mathrm{cp} / \mathrm{glu}}$ was restricted in subgroup who received glucose-lowering therapies or in subgroup with long-term of diabetic duration (Additional file 2: Figure S1 and Additional file 1: Table S1). Collectively, our study provided further evidence for the independent association of serum FABP4 levels with indices of islet $\beta$-cell function in T2D in the real world clinical practice.

The possible mechanisms for increased serum FABP4 linking to blunted insulin sensitivity may be as follows: first, overexpression of FABP4 contributes to endoplasmic reticulum stress, inflammatory response and oxidative stress [34], which in turn may lead to insulin resistance; second, elevated serum FABP4 levels are accompanied visceral adiposity, including ectopic fat deposition in islets of the pancreas, which may induce glucose intolerance, insulin resistance and $\beta$-cell dysfunction [35, 36]. The mechanisms for increased serum FABP4 linking to insulin secretion are also not well known, but some underlying mechanisms have been indirectly suggested. Serum FABP4 levels may result in insulin resistance, which in turn may lead to a compensatory increase in insulin secretion trying to maintain glucose homeostasis [37]. Additionally, in the basic studies, FABP4-deficient mice was found to have a reduction in insulin secretion $[38,39]$, which indicated that FABP4 participated in the insulin secretion; and FABP4 could potentiate glucose-stimulated insulin secretion in the presence of linoleic acid in vitro and in vivo. Moreover, neither FABP4 nor linoleic acid alone enhanced insulin secretion. Therefore, FABP4 and fatty acid have synergistic effect on $\beta$-cells to promote insulin secretion [16]. 


\section{Serum FABP4 levels and indices of pancreatic islet $a$-cell function}

Our present study may be the first to analyze the relationship between serum FABP4 levels and indices of pancreatic $\alpha$-cell function, and we found that increased serum FABP4 levels were associated with elevated fasting and postchallenge glucagon levels (Gluca $a_{0 \min }$ and $\mathrm{AUC}_{\text {gluca }}$ ) during OGTT in patients with T2D. In a previous study with 106 patients with T2D, Demant et al [40] identified that fasting glucagon levels were influenced by visceral fat deposition, and visceral fat deposition was paralleled by increased serum FABP4 levels. Moreover, hepatic insulin resistance, assessed by HOMA-IR, may lead to fasting hyperglucagonaemia [41], and HOMA-IR was also paralleled by increased serum FABP4 levels [32]. Additionally, palmitate can stimulate secretion of glucagon in isolated human islets via free fatty acid receptor at fasting glucose levels [42], and postprandial lipemia increased plasma glucagon concentrations in humans. Under a pathological condition such as obesity-induced oxidative stress, fatty acid (palmitate) would have relatively high affinity for FABP4, which would facilitate glucagon secretion from $\alpha$-cells [8]. Furthermore, in pancreatic islets, $\beta$-cells and other cells (such as $\alpha-, \delta$ - and PP-cells) would lose their identities under some certain conditions, such as glucolipotoxicity [43-45]. In a basic study with mouse, pancreatic islet $\beta$-cells were found to be transdifferentiated into $\alpha$-cells when the $\beta$-cell-specific FoxO1 was inhibited under the condition of the glucotoxicity [45, 46]. In human studies with T2D, islet $\beta$-cell dysfunction was partly caused by transdifferentiation of $\beta$-cells into $\alpha$-cells under glucolipotoxicity [44, 47]. FABP4 regulated the fatty acids, and may participate in the progress of transdifferentiation of $\beta$-cells into $\alpha$-cells under lipotoxicity. Collectively, our study and the indirect evidence of previous studies showed increased serum FABP4 levels may account for the elevated fasting and postchallenge glucagon.

\section{Limitations}

Our study has certain limitations. First of all, this study is a cross-sectional study that analyzed the correlations between serum FABP4 levels and pancreatic $\beta$-cell and $\alpha$-cell functions. It is difficult to determine the causality of serum FABP4 levels and indices of islet $\beta$-cell and $\alpha$-cell functions, so follow-up studies or basic researches are needed. Second, although relationship serum FABP4 levels and indices of islet $\beta$-cell and $\alpha$-cell functions remain significant after adjusting for the glucose-lowering therapies, some antidiabetic drugs such as DPP-4Is may have impact on the levels of serum FABP4 [48]. Third, the golden standard for evaluating pancreatic $\beta$-cell functions is the glucose clamp test and the derivative indicators calculated from OGTT may not be able to replace assessments of insulin sensitivity and insulin secretion of $\beta$-cells. However, the glucose clamp test is too complicated and difficult to be applied in the clinical practice. Finally, the recruited populations of this study were Chinese and came from the same hospital, so our findings may not be extrapolated to other populations.

\section{Conclusions}

Increased serum FABP4 levels were closely associated with blunted insulin sensitivity, increased insulin secretion, and elevated fasting and postchallenge glucagon levels in patients with T2D, which implied that excessive expression of FABP4 may get involved in the pancreatic islet $\beta$-cell and $\alpha$-cell dysfunctions.

\section{Abbreviations}

FABP4: Fatty acid-binding protein 4; T2D: Type 2 diabetes; OGTT: Oral glucose tolerance test; $I S I_{M-c p}$ : Matsuda index using $C$ peptide; $A_{\mathcal{M}} C_{\mathrm{cp} / \mathrm{glu}}$ : Ratio of the area under the $C$ peptide curve to the glucose curve; Gluca $_{0 \text { min: }}$ Fasting glucagon; $\mathrm{AUC}_{\text {gluca: }}$ : Area under the glucagon curve; DR: Diabetic retinopathy; DN: Diabetic nephropathy; CAD: Coronary artery disease; AIS: Acute ischemic stroke; HC: Healthy controls; FPG: Fasting plasma glucose; WC: Waist circumference; BMI: Body mass index; SBP: Systolic blood pressure; DBP: Diastolic blood pressure; AGls: a-Glucosidase inhibitors; GLP-1RAs: Glucagon-like peptide-1 receptor agonists; DPP-4Is: Dipeptidyl peptidase-4 inhibitors; HDLC: Highdensity lipoprotein cholesterol; LDLC: Low-density lipoprotein cholesterol; TG: Triglycerides; TC: Total cholesterol; UA: Uric acid; HbA1c: Glycosylated hemoglobin; eGFR: Estimated glomerular filtration rate; HOMA-IR: Homeostasis model assessment of insulin resistance.

\section{Supplementary Information}

The online version contains supplementary material available at https://doi. org/10.1186/s13098-021-00690-z.

Additional file1: Table S1. The relationships between serum InFABP4 and indices of islet $\beta$-cell and a-cell functions in T2D patients with different diabetic duration.

Additional file2: Figure S1. The relationships between serum FABP4 and islet $\beta$-cell function indices in two subgroups of T2D patients without any glucose-lowering therapy $(\mathrm{n}=32)(\mathbf{a}$ and $\mathbf{b})$ and with glucose-lowering therapies $(\mathrm{n}=83)$ ( $\mathbf{c}$ and $\mathbf{d})$

Additional file3: Figure S2. The relationships between serum FABP4 and islet $\beta$-cell function indices in patients with T2D after adjusting for the glucose-lowering therapies.

Additional file4: Figure S3. The relationship between serum FABP4 and AUC $_{\mathrm{cp0} 0-30 \mathrm{~min}}$ in patients with T2D.

\section{Acknowledgements}

Not applicable.

\section{Authors' contributions}

$\mathrm{HW}, \mathrm{JbS}$ and XqW participated in the conception and design of the study, and analyzed the data of study. HW drafted the initial manuscript, JbS and XqW revised the manuscript. HW, JC, XW, DmZ and XhW participated in data collection. All authors have read and approved the final manuscript. 


\section{Funding}

The study was funded by the Social Development Projects of Nantong (MS12019019, HS2020005), and the Medical Research Project of Nantong Health Commission (MB2019010).

\section{Availability of data and materials}

The current data are available to all interested researchers upon reasonable request. Requests for access to data should be made to the principal investigators of the study.

\section{Declarations}

\section{Ethics approval and consent to participate}

The study was approved by the Ethics Committee of Affiliated Hospital 2 of Nantong University and conducted after each participant provided informed consent before they were included into the study.

\section{Consent for publication}

Not applicable.

\section{Competing interests}

The authors declare that they have no conflict of interest.

\section{Author details}

${ }^{1}$ Department of Endocrinology, Affiliated Hospital 2 of Nantong University, and First People's Hospital of Nantong City, No. 6, Haierxiang North Road, Nantong 226001, China. ${ }^{2}$ Medical Research Center, Affiliated Hospital 2 of Nantong University, and First People's Hospital of Nantong City, No. 6, Haierxiang North Road, Nantong 226001, China.

\section{Received: 1 April 2021 Accepted: 11 June 2021}

Published online: 26 June 2021

\section{References}

1. Wajchenberg BL. beta-cell failure in diabetes and preservation by clinical treatment. Endocr Rev. 2007;28:187-218.

2. Rodriguez-Diaz R, Tamayo A, Hara M, Caicedo A. The local paracrine actions of the pancreatic alpha-cell. Diabetes. 2020;69:550-8.

3. Moon JS, Won KC. Pancreatic alpha-cell dysfunction in type 2 diabetes: old kids on the block. Diabetes Metab J. 2015:39:1-9.

4. Festa A, Williams K, D'Agostino R Jr, Wagenknecht LE, Haffner SM. The natural course of beta-cell function in nondiabetic and diabetic individuals: the insulin resistance atherosclerosis study. Diabetes. 2006;55:1114-20.

5. Knop FK, Vilsboll T, Madsbad S, Holst JJ, Krarup T. Inappropriate suppression of glucagon during OGTT but not during isoglycaemic i.v. glucose infusion contributes to the reduced incretin effect in type 2 diabetes mellitus. Diabetologia. 2007;50:797-805.

6. Cryer PE. Minireview: Glucagon in the pathogenesis of hypoglycemia and hyperglycemia in diabetes. Endocrinology. 2012;153:1039-48.

7. Dunning BE, Gerich JE. The role of alpha-cell dysregulation in fasting and postprandial hyperglycemia in type 2 diabetes and therapeutic implications. Endocr Rev. 2007;28:253-83.

8. Furuhashi M. Fatty acid-binding protein 4 in cardiovascular and metabolic diseases. J Atheroscler Thromb. 2019;26:216-32.

9. Djoussé L, Khawaja O, Bartz TM, Biggs ML, Ix JH, Zieman SJ, et al. Plasma fatty acid-binding protein 4, nonesterified fatty acids, and incident diabetes in older adults. Diabetes care. 2012;35:1701-7.

10. Tso AW, Xu A, Sham PC, Wat NM, Wang Y, Fong CH, et al. Serum adipocyte fatty acid binding protein as a new biomarker predicting the development of type 2 diabetes: a 10-year prospective study in a Chinese cohort. Diabetes Care. 2007;30:2667-72.

11. Zhang XZ, Tu WJ, Wang H, Zhao Q, Liu Q, Sun L, et al. Circulating serum fatty acid-binding protein 4 levels predict the development of diabetic retinopathy in type 2 diabetic patients. Am J Ophthalmol. 2018;187:71-9.

12. Yeung DC, Xu A, Tso AW, Chow WS, Wat NM, Fong CH, et al. Circulating levels of adipocyte and epidermal fatty acid-binding proteins in relation to nephropathy staging and macrovascular complications in type 2 diabetic patients. Diabetes Care. 2009;32:132-4.
13. Li S, Bi P, Zhao W, Lian Y, Zhu H, Xu D, et al. Prognostic utility of fatty acidbinding protein 4 in patients with type 2 diabetes and acute ischemic stroke. Neurotox Res. 2018:33:309-15.

14. Seo DH, Nam M, Jung M, Suh YJ, Ahn SH, Hong S, et al. Serum levels of adipocyte fatty acid-binding protein are associated with rapid renal function decline in patients with type 2 diabetes mellitus and preserved renal function. Diabetes Metab J. 2020;44:875-86.

15. Nakamura R, Okura T, Fujioka Y, Sumi K, Matsuzawa K, Izawa S, et al. Serum fatty acid-binding protein 4 (FABP4) concentration is associated with insulin resistance in peripheral tissues a clinical study. PLoS ONE. 2017:12:e0179737.

16. Wu LE, Samocha-Bonet D, Whitworth PT, Fazakerley DJ, Turner N, Biden $\mathrm{TJ}$, et al. Identification of fatty acid binding protein 4 as an adipokine that regulates insulin secretion during obesity. Mol Metab. 2014;3:465-73.

17. American Diabetes Association. 2 Classification and diagnosis of diabetes. Diabetes Care. 2015;38(Suppl 1):S8-16.

18. Levey AS, Coresh J, Greene T, Stevens LA, Zhang YL, Hendriksen S, et al. Using standardized serum creatinine values in the modification of diet in renal disease study equation for estimating glomerular filtration rate. Ann Intern Med. 2006;145(4):247-54.

19. Radaelli T, Farrell KA, Huston-Presley L, Amini SB, Kirwan JP, McIntyre HD, et al. Estimates of insulin sensitivity using glucose and C-Peptide from the hyperglycemia and adverse pregnancy outcome glucose tolerance test. Diabetes Care. 2010;33:490-4.

20. Cabre A, Lazaro I, Cofan M, Jarauta E, Plana N, Garcia-Otin AL, et al. FABP4 plasma levels are increased in familial combined hyperlipidemia. J Lipid Res. 2010;51:1173-8.

21. Zhang $S$, Yang $L$, Chen $P$, Jin $H$, Xie X, Yang M, et al. Circulating adipocyte fatty acid binding protein (FABP4) levels are associated with irisin in the middle-aged general Chinese population. PLoS ONE. 2016;11:e0146605.

22. Spurna J, Karasek D, Kubickova V, Goldmannova D, Krystynik O, Schovanek J, et al. Relationship of selected adipokines with markers of vascular damage in patients with type 2 diabetes. Metab Syndr Relat Disord. 2018;16:246-53.

23. Wu YW, Chang TT, Chang CC, Chen JW. Fatty-acid-binding protein 4 as a novel contributor to mononuclear cell activation and endothelial cell dysfunction in atherosclerosis. Int J Mol Sci. 2020;21:9245.

24. Furuhashi M, Hotamisligil GS. Fatty acid-binding proteins: role in metabolic diseases and potential as drug targets. Nat Rev Drug Discov. 2008;7:489-503.

25. Aragones G, Ferre R, Lazaro I, Cabre A, Plana N, Merino J, et al. Fatty acidbinding protein 4 is associated with endothelial dysfunction in patients with type 2 diabetes. Atherosclerosis. 2010;213:329-31.

26. Kim SJ, Chae S, Kim H, Mun DG, Back S, Choi HY, et al. A protein profile of visceral adipose tissues linked to early pathogenesis of type 2 diabetes mellitus. Mol Cell Proteomics. 2014;13:811-22.

27. Lee JJ, Britton KA, Pedley A, Massaro JM, Speliotes EK, Murabito JM, et al. Adipose tissue depots and their cross-sectional associations with circulating biomarkers of metabolic regulation. J Am Heart Assoc. 2016;5:e002936.

28. Coe NR, Bernlohr DA. Physiological properties and functions of intracellular fatty acid-binding proteins. Biochim Biophys Acta. 1998;1391:287-306.

29. Ibarretxe D, Girona J, Plana N, Cabre A, Heras M, Ferre R, et al. FABP4 plasma concentrations are determined by acquired metabolic derangements rather than genetic determinants. Nutr Metab Cardiovasc Dis. 2015;25:875-80.

30. Xu A, Wang Y, Xu JY, Stejskal D, Tam S, Zhang J, et al. Adipocyte fatty acidbinding protein is a plasma biomarker closely associated with obesity and metabolic syndrome. Clin Chem. 2006;52:405-13.

31. Hu X, Ma X, Pan X, Luo Y, Xu Y, Xiong Q, et al. Association of androgen with gender difference in serum adipocyte fatty acid binding protein levels. Sci Rep. 2016;6:27762.

32. Niu G, Li J, Wang H, Ren Y, Bai J. Associations of A-FABP with anthropometric and metabolic indices and inflammatory cytokines in obese patients with newly diagnosed type 2 diabetes. Biomed Res Int. 2016;2016:9382092.

33. DeFronzo RA, Tobin JD, Andres R. Glucose clamp technique: a method for quantifying insulin secretion and resistance. Am J Physiol. 1979;237:E214-23.

34. Trojnar M, Patro-Malysza J, Kimber-Trojnar Z, Leszczynska-Gorzelak B, Mosiewicz J. Associations between fatty acid-binding protein 4-a 
proinflammatory adipokine and insulin resistance, gestational and type 2 diabetes mellitus. Cells. 2019;8:227.

35. Lee Y, Lingvay I, Szczepaniak LS, Ravazzola M, Orci L, Unger RH. Pancreatic steatosis: harbinger of type 2 diabetes in obese rodents. Int J Obes. 2010;34:396-400

36. Zheng S, Ren X, Han T, Chen Y, Qiu H, Liu W, et al. Fenofibrate attenuates fatty acid-induced islet beta-cell dysfunction and apoptosis via inhibiting the NF-kappaB/MIF dependent inflammatory pathway. Metabolism. 2017:77:23-38.

37. Defronzo RA. From the triumvirate to the ominous octet: a new paradigm for the treatment of type 2 diabetes mellitus. Diabetes. 2009;58:773-95.

38. Maeda K, Cao H, Kono K, Gorgun CZ, Furuhashi M, Uysal KT, et al. Adipocyte/macrophage fatty acid binding proteins control integrated metabolic responses in obesity and diabetes. Cell Metab. 2005;1:107-19.

39. Scheja L, Makowski L, Uysal KT, Wiesbrock SM, Shimshek DR, Meyers DS, et al. Altered insulin secretion associated with reduced lipolytic efficiency in aP2-/- mice. Diabetes. 1999;48:1987-94.

40. Demant M, Bagger Jl, Suppli MP, Lund A, Gyldenlove M, Hansen KB, et al. Determinants of fasting hyperglucagonemia in patients with type 2 diabetes and nondiabetic control subjects. Metab Syndr Relat Disord. 2018;16:530-6.

41. Wewer Albrechtsen NJ, Faerch K, Jensen TM, Witte DR, Pedersen J, Mahendran Y, et al. Evidence of a liver-alpha cell axis in humans: hepatic insulin resistance attenuates relationship between fasting plasma glucagon and glucagonotropic amino acids. Diabetologia. 2018;61:671-80.

42. Kristinsson H, Sargsyan E, Manell H, Smith DM, Gopel SO, Bergsten P. Basal hypersecretion of glucagon and insulin from palmitate-exposed human islets depends on FFAR1 but not decreased somatostatin secretion. Sci Rep. 2017;7:4657.

43. Christensen AA, Gannon M. The beta cell in type 2 diabetes. Curr Diab Rep. 2019;19:81.

44. Prentki M, Peyot ML, Masiello P, Madiraju SRM. Nutrient-induced metabolic stress, adaptation, detoxification, and toxicity in the pancreatic beta-cell. Diabetes. 2020;69:279-90.

45. Kitamura T. The role of FOXO1 in beta-cell failure and type 2 diabetes mellitus. Nat Rev Endocrinol. 2013:9:615-23.

46. Talchai C, Xuan S, Lin HV, Sussel L, Accili D. Pancreatic beta cell dedifferentiation as a mechanism of diabetic beta cell failure. Cell. 2012;150:1223-34.

47. Wysham C, Shubrook J. Beta-cell failure in type 2 diabetes: mechanisms, markers, and clinical implications. Postgrad Med. 2020;132:676-86.

48. Furuhashi M, Sakuma I, Morimoto T, Higashiura Y, Sakai A, Matsumoto $\mathrm{M}$, et al. Treatment with anagliptin, a DPP-4 inhibitor, decreases FABP4 concentration in patients with type 2 diabetes mellitus at a high risk for cardiovascular disease who are receiving statin therapy. Cardiovasc Diabetol. 2020;19:89.

\section{Publisher's Note}

Springer Nature remains neutral with regard to jurisdictional claims in published maps and institutional affiliations.
Ready to submit your research? Choose BMC and benefit from:

- fast, convenient online submission

- thorough peer review by experienced researchers in your field

- rapid publication on acceptance

- support for research data, including large and complex data types

- gold Open Access which fosters wider collaboration and increased citations

- maximum visibility for your research: over 100M website views per year

At BMC, research is always in progress.

Learn more biomedcentral.com/submissions 